J. Dairy Sci. 92:49-57

doi:10.3168/jds.2008-1319

(c) American Dairy Science Association, 2009.

\title{
The accelerated ripening of cholesterol-reduced Cheddar cheese by crosslinked $\beta$-cyclodextrin
}

\author{
K. H. Seon, J. Ahn, and H. S. Kwak ${ }^{1}$ \\ Department of Food Science and Technology, Sejong University, Seoul 143-747, Korea
}

\begin{abstract}
This study was carried out to investigate the influence of salt content on cholesterol-reduced Cheddar cheese obtained by a treatment with crosslinked $\beta$-cyclodextrin $(\beta-C D)$ and to find if the ripening process was accelerated in cholesterol-reduced cheese. The crosslinked $\beta$-CD used was made by adipic acid. A primary study indicated that the chemical and rheological properties were not changed by the salt addition and the composition of Cheddar cheese treated with crosslinked $\beta-C D$ was similar to untreated Cheddar cheese. Approximately 91 to $92 \%$ cholesterol reduction was observed in the cheeses that were treated using $\beta$-CD. In a subsequent study, we found accelerated ripening by the crosslinked $\beta$-CD based on the productions of short-chain free fatty acids and free amino acids. In rheological properties, elasticity, cohesiveness, and gumminess scores in the cholesterol-reduced Cheddar cheese were significantly greater at $5 \mathrm{wk}$ ripening than those in the control at 4 mo ripening. At the early stage of ripening, most flavor properties such as rancidity, bitterness, and offflavor in the cholesterol-reduced cheese were greater. With ripening, however, those scores changed to similar or lower scores than those in the control. The present study indicated that the crosslinked $\beta$-CD treatment for cholesterol removal showed accelerated ripening effect on the properties of Cheddar cheese.
\end{abstract}

Key words: Cheddar cheese, crosslinked $\beta$-cyclodextrin, cholesterol removal, accelerated ripening

\section{INTRODUCTION}

The quality of cheese, as perceived by the consumer, will pass through a maximum during ripening. The characteristic properties (i.e., flavor and consistency) take a certain time to develop (Walstra et al., 1999). Storage and maintenance of cheese are expensive because of investments in buildings and machinery and

Received May 1, 2008.

Accepted September 11, 2008.

${ }^{1}$ Corresponding author: kwakhs@sejong.ac.kr costs of energy and labor. Reducing the ripening time is therefore attractive from an economic point of view. Acceleration of cheese ripening offers undoubted economic and technological advantages to producers (Fox, 1989a). The use of elevated ripening temperatures to accelerate proteolysis is one of the most practical methods to accelerate ripening (Law, 1984; Aston et al., 1985; Fox and McSweeney, 1998; O'Reilly et al., 2003). In addition, Yokoyama et al. (1992) filed a patent for acceleration of cheese ripening using high pressure, which reported that Cheddar cheese could be ripened in $3 \mathrm{~d}$ by treatment at $50 \mathrm{MPa}$, compared with a $6-\mathrm{mo}$ ripening period for conventional Cheddar cheese.

The ripening of Cheddar cheese involves a concerted series of microbiological, biochemical, and physicochemical changes that are collectively responsible for the development of its texture, flavor, and aroma (McSweeney, 2004). Accelerated cheese ripening processes are primarily aimed at accelerated flavor formation (i.e., a strong proteolysis or lipolysis), while maintaining a satisfactory texture. Most studies on the acceleration of cheese ripening were done by incorporating various proteolytic enzymes into milk or cheese curds during cheese manufacture (O'Keeffe et al., 1978; Kwak et al., 1989). During ripening, the cheese casein is hydrolyzed into peptides and free amino acids (FAA), and milk fat into FFA to have authentic cheese flavor and texture (Morris 1978; Fox, 1989b). Texture is one of the primary quality attributes of Cheddar cheese, with its development being inextricably linked with the biochemical and physicochemical changes that occur during ripening (Lucey et al., 2003). To date, the exact mechanisms responsible for texture development of Cheddar cheese during ripening have not been fully elucidated.

In our previous study (Kwak et al., 2002), it was reported that cream treated with $\beta$-cyclodextrin $(\boldsymbol{\beta}-\mathbf{C D})$ before cheese manufacture showed accelerated ripening in Cheddar cheese. Based on those findings, the objectives of this study were to examine the influence of salt content on properties of cholesterol-reduced Cheddar cheese and whether crosslinked $\beta-C D$ treatment may have an effect on ripening acceleration on Cheddar cheese or not. 
Table 1. Gross composition, yield, and cholesterol removal for control and cholesterol-reduced (CR) cheeses with differing salt content

\begin{tabular}{lccccc}
\hline Cheese type & Moisture & Fat & Protein & Yield & Cholesterol removal \\
\hline Control $^{1}$ & $40.2 \pm 1.2^{\mathrm{a}}$ & $37.5 \pm 3.0^{\mathrm{a}}$ & $27.7 \pm 2.2^{\mathrm{a}}$ & $10.1 \pm 0.1^{\mathrm{a}}$ & - \\
CR-1.0\% $^{2}$ & $45.1 \pm 2.1^{\mathrm{b}}$ & $37.1 \pm 2.6^{\mathrm{a}}$ & $27.5 \pm 1.3^{\mathrm{a}}$ & $11.5 \pm 0.2^{\mathrm{b}}$ & $91.9 \pm 3.3^{\mathrm{a}}$ \\
$\mathrm{CR}-1.5 \%$ & $44.9 \pm 2.9^{\mathrm{b}}$ & $36.7 \pm 1.6^{\mathrm{a}}$ & $27.5 \pm 1.1^{\mathrm{a}}$ & $11.8 \pm 0.2^{\mathrm{b}}$ & $90.8 \pm 2.2^{\mathrm{a}}$ \\
$\mathrm{CR}-2.0 \%$ & $43.6 \pm 1.2^{\mathrm{ab}}$ & $36.3 \pm 3.1^{\mathrm{a}}$ & $27.2 \pm 0.9^{\mathrm{a}}$ & $12.4 \pm 0.1^{\mathrm{b}}$ & $91.9 \pm 1.8^{\mathrm{a}}$ \\
$\mathrm{CR}-2.5 \%$ & $44.7 \pm 1.0^{\mathrm{b}}$ & $37.2 \pm 2.2^{\mathrm{a}}$ & $27.1 \pm 1.2^{\mathrm{a}}$ & $11.6 \pm 0.3^{\mathrm{b}}$ & $90.6 \pm 2.2^{\mathrm{a}}$ \\
CR-3.0\% & $41.6 \pm 2.4^{\mathrm{a}}$ & $37.8 \pm 1.0^{\mathrm{a}}$ & $27.0 \pm 2.0^{\mathrm{a}}$ & $10.9 \pm 0.2^{\mathrm{a}}$ & $91.9 \pm 1.2^{\mathrm{a}}$ \\
\hline
\end{tabular}

${ }^{\mathrm{a}, \mathrm{b}}$ Means within a column with different letters differ significantly $(P<0.05)$.

${ }^{1}$ Cream was not treated with $\beta$-cyclodextrin $(\beta-C D)$.

${ }^{2}$ After cream separation, cream was treated with crosslinked $\beta-C D$ and blended with skim milk at $70.4 \mathrm{~kg} / \mathrm{cm}^{2}$.

Salt concentration for each treatment is given as a percentage.

\section{MATERIALS AND METHODS}

\section{Materials}

Raw milk was obtained from Biggrae Dairy Plants (Kyunggi-do, Korea). Commercial $\beta$-CD (purity 99.1\%) was purchased from Nihon Shokuhin Cako Co. Ltd. (Osaka, Japan). Cholesterol and 5 $\alpha$-cholestane were purchased from Sigma Chemical Co. (St. Louis, MO), and all solvents were gas chromatography grade.

\section{Milk Treatment and Cholesterol Removal}

Bulk raw milk was pasteurized at $72^{\circ} \mathrm{C}$ for $15 \mathrm{~s}$ and cream was separated at $50^{\circ} \mathrm{C}$ using a cream separator (CE Elecrem, Vanves, France). Pasteurized cream (15 $\mathrm{kg}$ ) was stirred with $10 \%$ crosslinked $\beta$-CD at 1,400 rpm with a blender (Tops, Misung Co., Seoul, Korea) in a temperature-controlled water bath at $40^{\circ} \mathrm{C}$ for 30 min, and then centrifuged at $166 \times g$ for 10 min to remove $\beta$-CD. All treatments were run in triplicate (Han et al., 2005). The cholesterol-removed cream was mixed with skim milk at $70.4 \mathrm{~kg} / \mathrm{cm}^{2}$ (HC 5,000, Microfluidics Corp., Newton, MA).

\section{Manufacture of Cheddar Cheese}

The cholesterol-reduced milk (15 kg) was warmed to $36^{\circ} \mathrm{C}$. A frozen concentrated direct vat set mesophilic lactic acid starter culture for Cheddar cheese (R-703, Chr. Hansen's Lab., Copenhagen, Denmark) was added to the milk. The cheese making process was described by Metzger and Mistry (1994). After manufacturing, to study the effect of salt addition on properties of cholesterol-reduced Cheddar cheese, 5 concentrations of salt $(0,1.0,1.5,2.0,2.5$, or $3.0 \%)$ were added. Then, the pressed cheeses were weighed and vacuum packaged in a barrier bag for ripening at $5^{\circ} \mathrm{C}$. In a preliminary experiment, we found that the cholesterol-reduced cheese obtained by $\beta-\mathrm{CD}$ treatment ripened faster than conventional Cheddar cheese; consequently, we fixed sampling points as follows: the control cheese was manufactured from whole milk, salted $2 \%$, and ripened for $0,2,4,6$, and $8 \mathrm{mo}$ and cholesterol-reduced cheeses were ripened for $1,3,5,7$, and 9 wk. The cheese-making experiment was carried out in triplicate as 3 controls and 3 cholesterol-reduced samples and each batch of cheese making was divided into different salt concentrations.

Table 2. Short-chain free fatty acid content for control and cholesterol-reduced (CR) cheeses with differing salt content

\begin{tabular}{lccccr}
\hline & \multicolumn{5}{c}{ Short-chain FFA concentration (ppm) } \\
\cline { 2 - 6 } Treatment & $\mathrm{C}_{4}$ & $\mathrm{C}_{6}$ & $\mathrm{C}_{8}$ & $\mathrm{C}_{10}$ & \multicolumn{1}{c}{ Total } \\
\hline Control $^{1}$ & $2.7 \pm 0.2^{\mathrm{a}}$ & $2.2 \pm 0.1^{\mathrm{a}}$ & $2.4 \pm 0.2^{\mathrm{b}}$ & $2.9 \pm 0.2^{\mathrm{b}}$ & $10.2 \pm 0.5^{\mathrm{b}}$ \\
CR-1.0\% $^{\mathrm{b}}$ & $2.8 \pm 0.2^{\mathrm{a}}$ & $2.2 \pm 0.2^{\mathrm{ab}}$ & $2.5 \pm 0.2^{\mathrm{b}}$ & $2.7 \pm 0.1^{\mathrm{b}}$ & $10.2 \pm 0.4^{\mathrm{b}}$ \\
CR-1.5\% & $3.3 \pm 0.2^{\mathrm{b}}$ & $2.0 \pm 0.1^{\mathrm{a}}$ & $1.6 \pm 0.1^{\mathrm{a}}$ & $1.7 \pm 0.1^{\mathrm{a}}$ & $8.6 \pm 0.3^{\mathrm{a}}$ \\
CR-2.0\% & $2.6 \pm 0.1^{\mathrm{a}}$ & $1.9 \pm 0.1^{\mathrm{a}}$ & $1.9 \pm 0.2^{\mathrm{a}}$ & $1.8 \pm 0.1^{\mathrm{a}}$ & $8.2 \pm 0.2^{\mathrm{a}}$ \\
CR-2.5\% & $3.3 \pm 0.1^{\mathrm{b}}$ & $2.7 \pm 0.1^{\mathrm{b}}$ & $1.4 \pm 0.1^{\mathrm{a}}$ & $2.7 \pm 0.1^{\mathrm{b}}$ & $10.1 \pm 0.2^{\mathrm{b}}$ \\
CR-3.0\% & $4.8 \pm 0.2^{\mathrm{c}}$ & $2.8 \pm 0.1^{\mathrm{b}}$ & $2.1 \pm 0.1^{\mathrm{b}}$ & $1.3 \pm 0.1^{\mathrm{a}}$ & $11.0 \pm 0.4^{\mathrm{c}}$ \\
\hline
\end{tabular}

${ }^{a-c}$ Means within a column with different letters differ significantly $(P<0.05)$.

${ }^{1}$ Cream was not treated with $\beta$-cyclodextrin $(\beta-C D)$.

${ }^{2}$ After cream separation, cream was treated with crosslinked $\beta$-CD and blended with skim milk at $70.4 \mathrm{~kg} / \mathrm{cm}^{2}$. Salt concentration for each treatment is given as a percentage. 


\section{Extraction and Determination of Cholesterol}

For the extraction of cholesterol, $1 \mathrm{~g}$ of cheese sample was placed in a screw-capped glass tube $(15 \mathrm{~mm} \times 180$ $\mathrm{mm})$, and $500 \mu \mathrm{L}$ of $5 \alpha$-cholestane $(1 \mathrm{mg} / \mathrm{mL})$ was added as an internal standard. The sample was saponified at $60^{\circ} \mathrm{C}$ for $30 \mathrm{~min}$ with $5 \mathrm{~mL}$ of $2 \mathrm{M}$ ethanolic potassium hydroxide solution (Adams et al., 1986). After cooling to room temperature, cholesterol was extracted with 5 $\mathrm{mL}$ of hexane (Adams et al., 1986). The process was repeated 4 times. The hexane layers were transferred to a round-bottomed flask and dried under vacuum. The extract was redissolved in $1 \mathrm{~mL}$ of hexane and was stored at $-20^{\circ} \mathrm{C}$ until analysis.

Total cholesterol was determined on a silica fused capillary column $(\mathrm{HP}-5,30 \mathrm{~m} \times 0.32 \mathrm{~mm}$ inner diameter $\times 0.25 \mu \mathrm{m}$ thickness) using Hewlett-Packard 5890A gas chromatograph (Palo Alto, CA) equipped with a flame-ionization detector. The temperatures of the injector and detector were 270 and $300^{\circ} \mathrm{C}$, respectively. The oven temperatures were programmed to increase from 200 to $300^{\circ} \mathrm{C}$ at $10^{\circ} \mathrm{C} / \mathrm{min}$ and hold for $20 \mathrm{~min}$ at $300^{\circ} \mathrm{C}$. Nitrogen was used as a carrier gas at a flow rate of $2 \mathrm{~mL} / \mathrm{min}$ with a split ratio of $1 / 50$. Quantitation of cholesterol was done by comparing the peak areas with a response of an internal standard.

The percentage of cholesterol reduction was calculated as followed: cholesterol reduction $(\%)=100-($ amount of cholesterol in $\beta$-CD-treated cheese $\times 100 /$ amount of cholesterol in control). Cholesterol determination for control was averaged with each batch of treatments.

\section{Analysis of Chemical Composition and Yield of Cheese}

Cheese was analyzed for moisture, fat, salt, and protein using the methods of the Association of Official Analytical Chemists (AOAC, 1984). Cheese yield was determined as weight of cheese $\times 100$ /weight of milk.

\section{Analysis of Short-Chain FFA}

Cheese samples $(1 \mathrm{~g})$ were removed periodically from the cheeses at $0,2,4,6$, and $8 \mathrm{wk}$, extracted with diethyl ether and hexane for $2 \mathrm{~h}$, and eluted through a $10-\mathrm{mm}$ inner diameter glass column containing neutral alumina, as described by Kwak et al. (1990). A Hewlett-Packard model 5880A gas chromatograph equipped with a flame ionization detector was used. The preparation of FFA was achieved using a $15 \mathrm{~m} \times 0.53 \mathrm{~mm}$ inner diameter Nukol fused-silica capillary column (Supelco Inc., Bellefonte, PA). The gas chromatograph was operated with helium carrier gas at $2 \mathrm{~mL} / \mathrm{min}$, hydrogen gas at 37 $\mathrm{mL} / \mathrm{min}$, and air at $300 \mathrm{~mL} / \mathrm{min}$. The column oven was 
Table 4. Rheological properties for control and cholesterol-reduced (CR) cheeses with differing salt content

\begin{tabular}{|c|c|c|c|c|c|}
\hline Treatment & Hardness (g) & Elasticity & Cohesiveness & Gumminess & Chewiness \\
\hline Control $^{1}$ & $145.8 \pm 4.2^{\mathrm{c}}$ & $57.0 \pm 2.1^{\mathrm{a}}$ & $43.5 \pm 0.9^{\mathrm{a}}$ & $97.8 \pm 3.0^{\mathrm{b}}$ & $49.3 \pm 3.8^{\mathrm{a}}$ \\
\hline CR- $1.0 \%^{2}$ & $155.9 \pm 5.4^{\mathrm{c}}$ & $72.7 \pm 3.0^{\mathrm{b}}$ & $43.4 \pm 2.3^{\mathrm{a}}$ & $63.6 \pm 2.1^{\mathrm{a}}$ & $56.3 \pm 4.9^{\mathrm{a}}$ \\
\hline CR-1.5\% & $122.2 \pm 3.2^{\mathrm{b}}$ & $81.7 \pm 3.7^{\mathrm{bc}}$ & $67.9 \pm 2.8^{\mathrm{c}}$ & $84.0 \pm 3.2^{\mathrm{ab}}$ & $69.2 \pm 3.2^{\mathrm{b}}$ \\
\hline CR-2.5\% & $129.0 \pm 2.7^{\mathrm{b}}$ & $85.7 \pm 4.6^{\mathrm{bc}}$ & $56.6 \pm 3.2^{\mathrm{b}}$ & $87.6 \pm 4.1^{\mathrm{ab}}$ & $89.4 \pm 4.0^{\mathrm{c}}$ \\
\hline CR-3.0\% & $101.5 \pm 3.9^{\mathrm{a}}$ & $65.6 \pm 1.2^{\mathrm{b}}$ & $43.3 \pm 4.0^{\mathrm{a}}$ & $100.0 \pm 2.9^{\mathrm{c}}$ & $94.8 \pm 3.2^{\mathrm{d}}$ \\
\hline
\end{tabular}

\footnotetext{
${ }^{\mathrm{a}-\mathrm{d}}$ Means within a column with different letters differ significantly $(P<0.05)$.

${ }^{1}$ Cream was not treated with $\beta$-cyclodextrin $(\beta-\mathrm{CD})$.

${ }^{2}$ After cream separation, cream was treated with crosslinked $\beta-\mathrm{CD}$ and blended with skim milk at $70.4 \mathrm{~kg} / \mathrm{cm}^{2}$. Salt concentration for each treatment is given as a percentage.
}

programmed for an initial holding for $1 \mathrm{~min}$ at $110^{\circ} \mathrm{C}$, heating to $180^{\circ} \mathrm{C}$ at $5^{\circ} \mathrm{C} / \mathrm{min}$ for $10 \mathrm{~min}$, and holding for $20 \mathrm{~min}$. The temperature for both the injector and detector was $250^{\circ} \mathrm{C}$. All qualitative analyses were done by relating each peak area of individual FFA to the peak area of tridecanoic acid as an internal standard. Each FFA was identified by the retention time of a standard.

\section{Analysis of FAA}

Reverse phase-HPLC analysis of the FAA was performed according to the method of Izco et al. (2000). Samples were analyzed on a Waters HPLC system (Waters Corp., Milford, MA) consisting of a 600 pump and a 486 tunable absorbance detector at $254 \mathrm{~nm}$. The column used was a Waters PicoTag $\mathrm{C}_{18}$ reversed-phase column maintained at $46^{\circ} \mathrm{C}$. For identification of amino acids, methionine sulfone was added as an internal standard. A gradient with 2 solvents was used to run the sample: solution $\mathrm{A}$, consisting of $70 \mathrm{~m} M$ sodium acetate adjusted to $\mathrm{pH} 6.55$ with acetic acid and containing $2.5 \%$ acetonitrile; and solution B, containing $45 \%$ acetonitrile, $40 \%$ water, and $15 \%$ methanol. Before each injection, the column was equilibrated with solvent A for $2 \mathrm{~min}$.

\section{Rheological Analysis}

Cylindrical samples $(2 \mathrm{~cm}$ diameter $\times 4.5 \mathrm{~cm}$ height) were cut, and force-distance curves were obtained using a Sun Rheometer (CR-200D, Sun Scientific Co., LTD., Tokyo. Japan) with a crosshead of $50 \mathrm{~nm} / \mathrm{min}$ and a chart speed of $100 \mathrm{~mm} / \mathrm{min}$. From these curves, the basic characteristics of the texture profile were determined, including hardness, elasticity, cohesiveness, gumminess, and chewiness. The point of greatest force during the first compression was the hardness. The extent to which the sample returned to its shape between the first and second compressions was the elasticity. The ratio of the area under the second compression curve was the cohesiveness. Gumminess and chewiness were calculated as hardness $\times$ cohesiveness and gumminess $\times$ elasticity, respectively.

\section{Sensory Analysis}

For the sensory test, cholesterol-reduced cheese was stored at $4^{\circ} \mathrm{C}$ for $0,2,4,6$, and 8 wk. A 10-member trained panel evaluated randomly coded Cheddar cheese. The texture, color, flavor, and taste were evaluated on a 7 -point scale $(1=$ very weak, $2=$ slightly weak, $3=$ weak, $4=$ moderate, $5=$ strong, $6=$ slightly

Table 5. Sensory characteristics for control and cholesterol-reduced (CR) cheeses with differing salt content

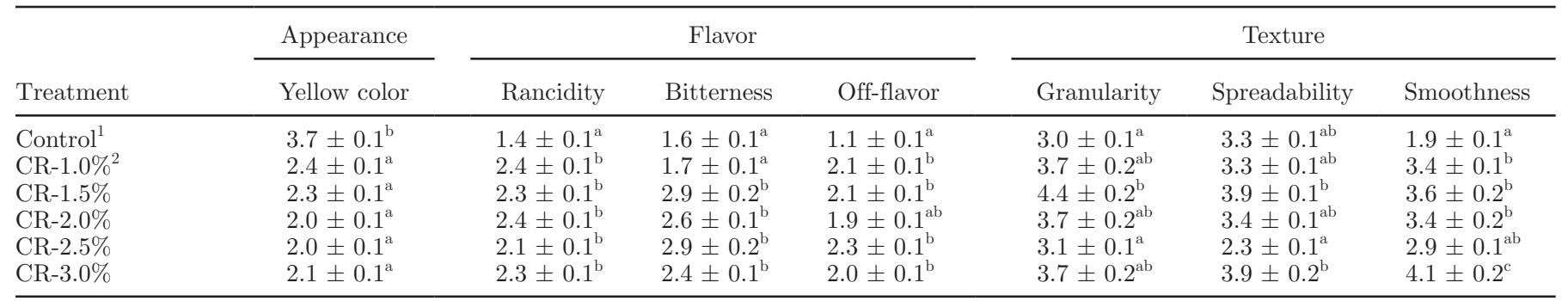

\footnotetext{
${ }^{\mathrm{a}-\mathrm{d}}$ Means within a column with different letters differ significantly $(P<0.05)$.

${ }^{1}$ Cream was not treated with $\beta$-cyclodextrin $(\beta$-CD).

${ }^{2}$ After cream separation, cream was treated with crosslinked $\beta$-CD and blended with skim milk at $70.4 \mathrm{~kg} / \mathrm{cm}^{2}$. Salt concentration for each treatment is given as a percentage.
} 
Table 6. Short-chain fatty acid content for control (R) and cholesterol-reduced (CR) cheeses ripened at $5^{\circ} \mathrm{C}$

\begin{tabular}{|c|c|c|c|c|c|}
\hline Treatment & \multicolumn{5}{|c|}{ Short-chain FFA concentration (ppm) } \\
\hline CR-1 wk $^{1}$ & $3.8 \pm 0.2^{\mathrm{a}}$ & $2.7 \pm 0.2^{\mathrm{a}}$ & $3.5 \pm 0.1^{\mathrm{a}}$ & $3.6 \pm 0.2^{\mathrm{a}}$ & $13.5 \pm 0.6^{\mathrm{a}}$ \\
\hline CR-3 wk & $8.8 \pm 1.0^{\mathrm{b}}$ & $4.2 \pm 0.2^{\mathrm{a}}$ & $5.5 \pm 1.1^{\mathrm{a}}$ & $5.6 \pm 0.4^{\mathrm{a}}$ & $23.9 \pm 4.3^{\mathrm{ab}}$ \\
\hline $\mathrm{R}-2$ mo & $14.0 \pm 2.2^{\mathrm{bc}}$ & $10.3 \pm 1.2^{\mathrm{b}}$ & $8.0 \pm 0.9^{\mathrm{ab}}$ & $12.1 \pm 1.7^{\mathrm{b}}$ & $44.2 \pm 5.2^{\mathrm{b}}$ \\
\hline CR-5 wk & $23.1 \pm 3.0^{\mathrm{c}}$ & $12.1 \pm 2.0^{\mathrm{b}}$ & $9.4 \pm 0.9^{\mathrm{ab}}$ & $17.1 \pm 1.5^{\mathrm{b}}$ & $61.7 \pm 5.6^{\mathrm{c}}$ \\
\hline CR-9 wk & $37.8 \pm 2.2^{\mathrm{d}}$ & $18.2 \pm 2.0^{\mathrm{bc}}$ & $22.0 \pm 1.3^{\mathrm{c}}$ & $30.0 \pm 2.1^{\mathrm{d}}$ & $108.9 \pm 6.4^{\mathrm{e}}$ \\
\hline $\mathrm{R}-8 \mathrm{mo}$ & $31.2 \pm 3.2^{\mathrm{cd}}$ & $20.7 \pm 1.2^{\mathrm{c}}$ & $19.9 \pm 2.8^{\mathrm{bc}}$ & $27.0 \pm 2.3^{\mathrm{cd}}$ & $98.6 \pm 7.7^{\mathrm{e}}$ \\
\hline
\end{tabular}

${ }^{\mathrm{a} e}$ Means within a column with different letters differ significantly $(P<0.05)$.

${ }^{1}$ After cream separation, cream was treated with crosslinked $\beta$-cyclodextrin $(\beta-\mathrm{CD})$ and blended with skim milk at $70.4 \mathrm{~kg} / \mathrm{cm}^{2}$.

${ }^{2}$ Cream was not treated with $\beta-C D$.

strong, and 7 = very strong). A randomized, balanced, complete block design was used (Cochran and Cox, $1957)$ that resulted in 2 replications for all samples.

\section{Statistical Analysis}

One-way ANOVA (SAS Institute, 1985) was used. The significance of the results was analyzed by the least significant difference test. Difference of $P<0.05$ was considered to be significant.

\section{RESULTS AND DISCUSSION}

\section{Global Composition}

As a first experiment, we attempted to find the optimal concentration of salt added to cholesterol-reduced Cheddar cheese to obtain chemical and rheological properties similar to those of the control cheese. In the composition of cholesterol-reduced cheese treated by crosslinked $\beta-C D$, moisture content of cheese was in the range of 41.6 to $45.1 \%$, fat 36.3 to $37.8 \%$, and protein 27.1 to $27.7 \%$ (Table 1). There was a significant difference between the control and the cholesterol-reduced cheese in moisture content. However, no difference was found in fat and protein contents. Treatment with $\beta-C D$ increased the cheese moisture content, which resulted from a slow curd drainage usually found in reduced-fat Cheddar cheese (Metzger and Mistry, 1994). In addition, $\beta$-CD treatment may increase the incorporation of casein or other protein compounds via fat-protein network. No change in fat content indicated that crosslinked $\beta-C D$ did not change the size of fat globules; therefore, no fat was released in manufacture of the cholesterol-reduced cheese.

\section{Short-Chain FFA}

No specific effect of salt addition was found in production of short-chain fatty acids (Table 2). In the control cheese and cholesterol-reduced cheese with $1 \%$ salt, similar amount of individual fatty acids were found, whereas $\mathrm{C}_{4}$ was increased in cholesterol-reduced cheeses containing $1.5 \%$ salt or greater concentrations. Total amount of short-chain FFA were similar to the control, 1 , and $2.5 \%$ salt-added groups. We did not find any trend relating lipolysis to salt content in the present study.

\section{FAA}

The determination of total FAA is shown in Table 3. No difference in the FAA content was observed between control and cholesterol-reduced cheeses at the beginning of the ripening (or after manufacture), regardless the level of salt. Free amino acid content ranged from 23.7 to $31.6 \mu \mathrm{mol}$ per $\mathrm{g}$ of cheese (Table 3 ).

\section{Rheological Characteristics}

The rheological properties of cholesterol-reduced Cheddar cheeses with different amounts of salt are shown in Table 4. Rheological properties in the cholesterol-reduced cheeses containing $1.0 \%$ salt were similar to those in the control except elasticity and chewiness. The control and 1\% salt-added cholesterol-reduced cheeses showed significantly higher hardness and lower chewiness scores compared with the other cheeses. The cohesiveness scores were similar in the control, $1 \%$ saltadded, and $3 \%$ salt-added cheeses, but others were significantly different. Elasticity scores were significantly 
higher in all cholesterol-reduced cheeses regardless of salt content. The gumminess score for the $1 \%$ salt-added cholesterol-reduced cheese was the lowest score of all the types of cheeses. Based on these results, we found that cholesterol-reduced cheeses with $1 \%$ salt were the most similar to control cheeses.

In general, the values for the texture profile analysis parameters hardness, cohesiveness, springiness, and chewiness decreased as ripening progressed (O'Mahony and McSweeney, 2005). It is known that moisture content and extent of primary proteolysis influence the rheological properties of cheese (Guinee, 2003). There was a significant $(P<0.05)$ reduction in the hardness of cholesterol-reduced cheeses except for $1.0 \%$ salt cheeses (O'Mahony and McSweeney, 2005). The significant $(P<0.05)$ reduction in hardness (i.e., softening) of the cholesterol-reduced cheese was due to the greater moisture content (Creamer and Olson, 1982).

\section{Sensory Characteristics}

The sensory attributes of cholesterol-reduced Cheddar cheese are shown in Table 5. The most significant difference was found in rancidity and off-flavor characteristics between the control and cholesterol-reduced cheese. Both rancidity and off-flavor in the cholesterolreduced cheese were significantly greater than those in the control. Bitterness also showed higher scores in all the cholesterol-reduced cheeses except for $1 \%$ added cheeses. In texture properties, both granularity and spreadability of cheeses with different levels of salt showed similar scores to the control. However, smoothness score in the cholesterol-reduced cheeses was higher than in the control.

\section{Ripening Study}

In the subsequent experiment, cholesterol-reduced cheeses containing $1 \%$ salt were compared with conventional control Cheddar cheeses during the ripening process. Ripening time was fixed at 9 wk for cholesterolreduced cheeses and at 8 mo for control cheeses.

\section{Short-Chain FFA}

The production of short-chain FFA was considered to be an important aspect of this study. The production of short-chain FFA in the control and cholesterol-reduced cheeses during storage is shown in Table 6. The total amount of short-chain FFA was significantly lower in the cholesterol-reduced cheese treated by the crosslinked $\beta-C D$ at early stages of ripening, for example, at 3 and 5 wk compared with the control at 2 and 4 mo ripening $(P<0.05)$. However, it increased sharply after

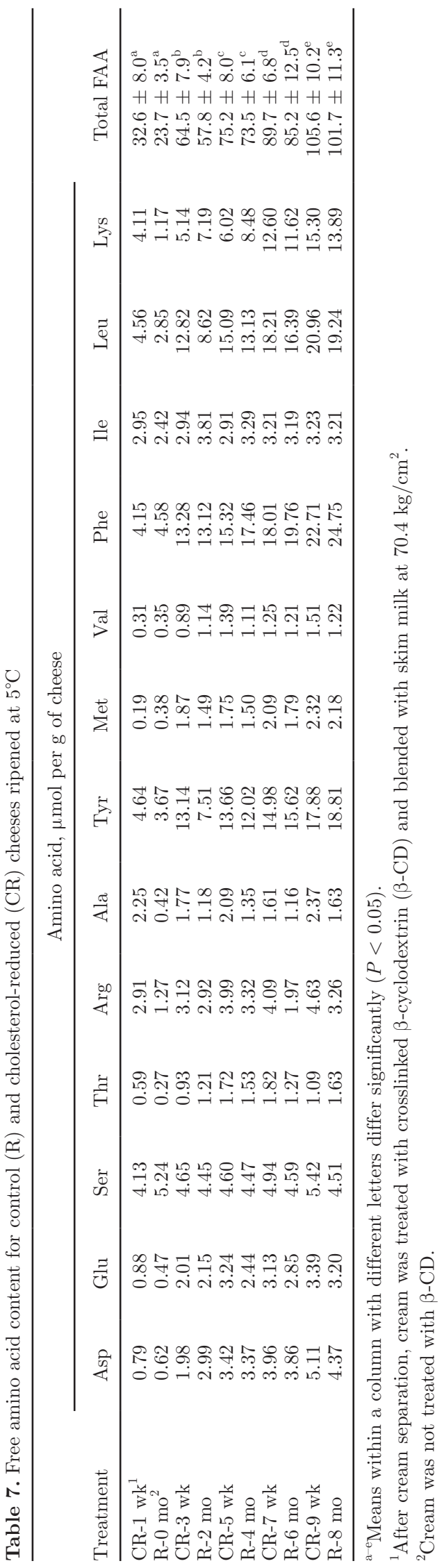


Table 8. Rheological properties for control (R) and cholesterol-reduced $(\mathrm{CR})$ cheeses ripened at $5^{\circ} \mathrm{C}$

\begin{tabular}{|c|c|c|c|c|c|}
\hline Treatment & Hardness & Elasticity & Cohesiveness & Gumminess & Chewiness \\
\hline CR-1 wk ${ }^{1}$ & $153.9 \pm 5.0^{\mathrm{a}}$ & $70.7 \pm 5.5^{\mathrm{c}}$ & $44.3 \pm 4.7^{\mathrm{b}}$ & $63.6 \pm 2.0^{\mathrm{b}}$ & $56.3 \pm 2.4^{\mathrm{a}}$ \\
\hline $\mathrm{R}-0 \mathrm{mo}^{2}$ & $145.8 \pm 4.2^{\mathrm{a}}$ & $57.0 \pm 2.1^{\mathrm{b}}$ & $43.5 \pm 0.9^{\mathrm{b}}$ & $97.8 \pm 3.0^{\mathrm{c}}$ & $49.3 \pm 3.8^{\mathrm{a}}$ \\
\hline CR-3 wk & $168.2 \pm 7.2^{\mathrm{a}}$ & $51.5 \pm 8.9^{\mathrm{b}}$ & $45.0 \pm 2.7^{\mathrm{b}}$ & $94.3 \pm 8.2^{\mathrm{c}}$ & $94.7 \pm 3.2^{\mathrm{c}}$ \\
\hline $\mathrm{R}-2 \mathrm{mo}$ & $237.5 \pm 23.2^{\mathrm{ab}}$ & $61.0 \pm 13.0^{\mathrm{b}}$ & $41.8 \pm 3.0^{\mathrm{b}}$ & $63.0 \pm 3.8^{\mathrm{b}}$ & $80.8 \pm 6.0^{\mathrm{b}}$ \\
\hline CR-5 wk & $164.8 \pm 19.8^{\mathrm{a}}$ & $59.8 \pm 10.2^{\mathrm{b}}$ & $42.0 \pm 3.5^{\mathrm{b}}$ & $81.9 \pm 6.3^{\mathrm{bc}}$ & $77.8 \pm 5.2^{\mathrm{b}}$ \\
\hline $\mathrm{R}-4 \mathrm{mo}$ & $434.3 \pm 17.0^{\mathrm{c}}$ & $29.5 \pm 7.5^{\mathrm{a}}$ & $33.8 \pm 5.2^{\mathrm{ab}}$ & $56.3 \pm 3.2^{\mathrm{ab}}$ & $77.0 \pm 8.9^{\mathrm{b}}$ \\
\hline CR-7 wk & $216.8 \pm 9.7^{\mathrm{ab}}$ & $55.8 \pm 5.8^{\mathrm{b}}$ & $55.8 \pm 3.7^{\mathrm{c}}$ & $65.4 \pm 8.1^{\mathrm{b}}$ & $61.0 \pm 5.6^{\mathrm{ab}}$ \\
\hline $\mathrm{R}-6 \mathrm{mo}$ & $537.9 \pm 27.9^{\mathrm{d}}$ & $26.9 \pm 4.0^{\mathrm{a}}$ & $24.4 \pm 1.2^{\mathrm{a}}$ & $52.2 \pm 2.6^{\mathrm{ab}}$ & $71.5 \pm 3.1^{\mathrm{b}}$ \\
\hline CR-9 wk & $279.4 \pm 13.2^{\mathrm{ab}}$ & $46.2 \pm 3.2^{\mathrm{b}}$ & $53.6 \pm 3.1^{\mathrm{c}}$ & $64.5 \pm 7.0^{\mathrm{b}}$ & $50.3 \pm 2.7^{\mathrm{a}}$ \\
\hline $\mathrm{R}-8 \mathrm{mo}$ & $555.9 \pm 33.2^{\mathrm{d}}$ & $22.4 \pm 3.1^{\mathrm{a}}$ & $17.9 \pm 1.2^{\mathrm{a}}$ & $42.7 \pm 5.1^{\mathrm{a}}$ & $63.4 \pm 6.5^{\mathrm{ab}}$ \\
\hline
\end{tabular}

${ }^{\mathrm{a}-\mathrm{d}}$ Means within a column with different letters differ significantly $(P<0.05)$.

${ }^{1}$ After cream separation, cream was treated with crosslinked $\beta$-cyclodextrin $(\beta-\mathrm{CD})$ and blended with skim milk at $70.4 \mathrm{~kg} / \mathrm{cm}^{2}$.

${ }^{2}$ Cream was not treated with $\beta-C D$.

7 and 8 wk of ripening, reaching similar values of those of control cheeses that ripened for 6 and 8 mo. In the control, the amount of total short-chain FFA increased from 9.17 to $98.64 \mathrm{ppm}$ in $8 \mathrm{mo}$, but it increased from 10.22 to $108.93 \mathrm{ppm}$ for the cholesterol-reduced Cheddar cheese at only 9 wk of ripening. These results indicate that the cholesterol-reduced Cheddar cheese ripening by crosslinked $\beta-C D$ accelerated faster than that with no treatment. With regard to FFA production, we may assume that small particles of fat due to $\beta$-CD treatment can be easily released from cheese curds in the process of cheese manufacture.

\section{FAA}

The production of total FAA during ripening is shown in Table 7. The principal amino acids present in both cheeses during ripening were tyrosine, phenylalanine, leucine, and lysine (Table 7). In agreement with these results, leucine and phenylalanine were also reported to be the most abundant FAA in miniature Cheddartype cheeses ripened at $8^{\circ} \mathrm{C}$ for 2 mo (O'Mahony et al.,
2003). Shakeel-Ur-Rehman et al. (2004) also reported glutamic acid, valine, leucine, and phenylalanine to be the most abundant FAA in Cheddar cheeses ripened at $8^{\circ} \mathrm{C}$ for $180 \mathrm{~d}$.

The cheeses made from $\beta$-CD-treated cream produced slightly lower amounts of individual FAA at an early stage of ripening period ( 1 and 3 wk) compared with the control (0 and $2 \mathrm{mo}$ ), respectively. Total amount of FAA was $104.55 \mu \mathrm{mol}$ per $\mathrm{g}$ of cheese in the control and $101.73 \mu \mathrm{mol}$ per $\mathrm{g}$ of cheese in the cholesterol-reduced cheese after $8 \mathrm{mo}$ and $9 \mathrm{wk}$ ripening periods, respectively. After 7 and 9 wk ripening, the total amount of FAA in cholesterol-reduced cheeses reached similar amounts of FAA to those of control cheeses at 6 and 8 mo. This suggests that the cheese made from $\beta$-CD-treated cream showed accelerated ripening in terms of FAA production, partly due to the accelerated proteolysis.

Proteolysis in cheese is caused by the action of the rennet retained in the curd, plasmin of the milk, and proteases and peptidases from the starter cultures used. Protease activity leads to a large amount of peptides, the so-called soluble-nitrogen fraction in a cheese. These

Table 9. Sensory characteristics for control (R) and cholesterol-reduced $(\mathrm{CR})$ cheeses ripened at $5^{\circ} \mathrm{C}$

\begin{tabular}{|c|c|c|c|c|c|c|c|}
\hline \multirow[b]{2}{*}{ Treatment } & \multirow{2}{*}{$\begin{array}{l}\text { Appearance } \\
\text { Yellow color }\end{array}$} & \multicolumn{3}{|c|}{ Flavor } & \multicolumn{3}{|c|}{ Texture } \\
\hline & & Rancidity & Bitterness & Off-flavor & Granularity & Spreadability & Smoothness \\
\hline CR-1 wk ${ }^{1}$ & $2.2 \pm 0.1^{\mathrm{a}}$ & $2.7 \pm 0.1^{\mathrm{b}}$ & $1.9 \pm 0.1^{\mathrm{a}}$ & $2.1 \pm 0.2^{\mathrm{b}}$ & $3.5 \pm 0.2^{\mathrm{ab}}$ & $3.3 \pm 0.2^{\mathrm{a}}$ & $3.4 \pm 0.2^{\mathrm{b}}$ \\
\hline $\mathrm{R}-0 \mathrm{mo}^{2}$ & $3.7 \pm 0.3^{\mathrm{b}}$ & $1.4 \pm 0.1^{\mathrm{a}}$ & $1.6 \pm 0.1^{\mathrm{a}}$ & $1.1 \pm 0.1^{\mathrm{a}}$ & $3.0 \pm 0.1^{\mathrm{a}}$ & $3.3 \pm 0.1^{\mathrm{a}}$ & $1.9 \pm 0.1^{\mathrm{a}}$ \\
\hline CR-3 wk & $2.9 \pm 0.2^{\mathrm{ab}}$ & $3.3 \pm 0.2^{\mathrm{bc}}$ & $2.7 \pm 0.2^{\mathrm{b}}$ & $2.6 \pm 0.2^{\mathrm{b}}$ & $3.3 \pm 0.3^{\mathrm{a}}$ & $3.1 \pm 0.2^{\mathrm{a}}$ & $3.1 \pm 0.3^{\mathrm{b}}$ \\
\hline $\mathrm{R}-2 \mathrm{mo}$ & $4.1 \pm 0.3^{\mathrm{bc}}$ & $1.7 \pm 0.1^{\mathrm{a}}$ & $1.9 \pm 0.1^{\mathrm{a}}$ & $1.6 \pm 0.2^{\mathrm{ab}}$ & $4.9 \pm 0.2^{\mathrm{c}}$ & $4.7 \pm 0.3^{\mathrm{c}}$ & $3.3 \pm 0.3^{\mathrm{b}}$ \\
\hline CR-5 wk & $3.1 \pm 0.1^{\mathrm{ab}}$ & $3.3 \pm 0.2^{\mathrm{bc}}$ & $3.9 \pm 0.2^{\mathrm{c}}$ & $2.1 \pm 0.1^{\mathrm{b}}$ & $4.3 \pm 0.3^{\mathrm{bc}}$ & $4.0 \pm 0.4^{\mathrm{ab}}$ & $3.7 \pm 0.3^{\mathrm{b}}$ \\
\hline $\mathrm{R}-4 \mathrm{mo}$ & $4.1 \pm 0.3^{\mathrm{bc}}$ & $3.3 \pm 0.3^{\mathrm{bc}}$ & $3.3 \pm 0.2^{\mathrm{bc}}$ & $3.7 \pm 0.3^{\mathrm{c}}$ & $5.0 \pm 0.4^{\mathrm{c}}$ & $4.7 \pm 0.4^{\mathrm{c}}$ & $3.6 \pm 0.2^{\mathrm{b}}$ \\
\hline CR-7 wk & $3.3 \pm 0.2^{\mathrm{ab}}$ & $3.7 \pm 0.2^{\mathrm{c}}$ & $4.0 \pm 0.4^{\mathrm{c}}$ & $3.1 \pm 0.2^{\mathrm{bc}}$ & $4.0 \pm 0.3^{\mathrm{b}}$ & $3.9 \pm 0.3^{\mathrm{ab}}$ & $3.7 \pm 0.2^{\mathrm{b}}$ \\
\hline $\mathrm{R}-6 \mathrm{mo}$ & $4.6 \pm 0.4^{\mathrm{c}}$ & $4.4 \pm 0.4^{\mathrm{cd}}$ & $4.9 \pm 0.3^{\mathrm{d}}$ & $3.7 \pm 0.3^{\mathrm{c}}$ & $4.3 \pm 0.4^{\mathrm{bc}}$ & $4.3 \pm 0.3^{\mathrm{b}}$ & $3.3 \pm 0.3^{\mathrm{b}}$ \\
\hline CR-9 wk & $3.7 \pm 0.2^{\mathrm{b}}$ & $4.7 \pm 0.3^{\mathrm{d}}$ & $4.7 \pm 0.3^{\mathrm{d}}$ & $2.9 \pm 0.3^{b c}$ & $5.1 \pm 0.3^{\mathrm{c}}$ & $5.1 \pm 0.4^{\mathrm{c}}$ & $4.3 \pm 0.3^{\mathrm{c}}$ \\
\hline $\mathrm{R}-8 \mathrm{mo}$ & $4.4 \pm 0.3^{\mathrm{c}}$ & $4.4 \pm 0.4^{\mathrm{cd}}$ & $5.9 \pm 0.4^{\mathrm{e}}$ & $3.6 \pm 0.4^{\mathrm{c}}$ & $5.3 \pm 0.4^{\mathrm{c}}$ & $4.9 \pm 3.2^{\mathrm{c}}$ & $3.4 \pm 0.2^{\mathrm{b}}$ \\
\hline
\end{tabular}

${ }^{\mathrm{a} e} \mathrm{M}$ Means within a column with different letters differ significantly $(P<0.05)$.

${ }^{1}$ After cream separation, cream was treated with crosslinked $\beta$-cyclodextrin $(\beta-\mathrm{CD})$ and blended with skim milk at $70.4 \mathrm{~kg} / \mathrm{cm}^{2}$.

${ }^{2}$ Cream was not treated with $\beta$-CD. 
peptides are further degraded to small peptides and FAA, the amino-nitrogen fraction in cheese. Protease and peptidase activities are dependent on the starter culture used. For this reason a lot of attention has been paid to the use of starter cultures and lactic acid bacteria, which enhance ripening and flavor formation in cheese (Smit et al., 2000; Yvon, 2006).

\section{Rheological Characteristics}

The effect of $\beta$-CD treatment on rheological properties of the cholesterol-reduced cheese is shown in Table 8. In hardness, the control showed a significant and continuous increase during the 8-mo ripening period from 145.50 to 555.88 , whereas that in a cholesterol-reduced cheese increased slightly during 9 wk of ripening from 153.8 to 279.4. Even though hardness increased in the cholesterol-reduced cheese hardness for 9 wk ripening, it could not reach similar values to control ripened for 8 mo. This result may be attributed by the high amount of moisture in the cholesterol-reduced Cheddar cheese.

In the cholesterol-reduced cheese, elasticity decreased from 70.7 to 46.2 during the 9-wk ripening period. Elasticity was always higher in the cholesterol-reduced cheese compared with the control, except at $3 \mathrm{wk}$ of ripening. Cohesiveness value in the cholesterol-reduced cheese was stable up to $5 \mathrm{wk}$ and increased thereafter, whereas it was continuously decreased in the control. In the cholesterol-reduced cheese, the highest gumminess was found at $3 \mathrm{wk}$ and decreased thereafter. Chewiness value in the cholesterol-reduced cheese up to 5 wk was greater than that of the control up to 4 mo; however, it was reversed thereafter. Based on these results, the elasticity, cohesiveness, and gumminess in the cholesterol-reduced cheese at 5 wk ripening were significantly higher than those in the control at 4 mo ripening. However, the significant low hardness scores in the cholesterol-reduced cheese needs to be studied more.

\section{Sensory Characteristics}

The sensory attributes of cholesterol-reduced cheese are shown in Table 9. In appearance, yellow color appeared to be greater in the control than in the cholesterol-reduced cheese at the beginning of the ripening. However, color was increased dramatically over score 3 in the cholesterol-reduced cheese, even though it was still lower compared with that of the control.

In flavor properties, cholesterol-reduced cheeses showed a sharp increase of rancidity, bitterness, and off-flavor after $3 \mathrm{wk}$ of ripening, exceeding the values in control cheeses ripened for 2 mo. However, after $5 \mathrm{wk}$ and $4 \mathrm{mo}$, the values were mostly lower in the cholesterol-reduced cheese compared with those in the control.

Another aspect we found in the study was an increase of bitterness score in the cholesterol-reduced cheese at $3 \mathrm{wk}$ of ripening and thereafter. This was probably due to a significant difference of amino acid production in the cholesterol-reduced cheese. Therefore, we may suggest that crosslinked $\beta$-CD treatment resulted in enhanced proteolysis, which could be one reason among other unknown factors. The larger increase in total and individual amino acids, including bitter amino acids, observed through the ripening period may reflect greater peptidase activity in the cholesterol-reduced cheese than in the control. Proteolysis in cheese during ripening results in an increase in peptides, which is directly related to bitterness (Fernandez-Espla and Fox, 1998; Smit et al., 2000). In texture properties, not much difference was found in granularity and spreadability between 1 wk of the cholesterol-reduced cheese and 0 mo of the control. However, the smoothness score in the cholesterol-reduced cheese was significantly higher than the control. The smoothness score was maintained throughout the ripening period in the cholesterolreduced cheese. The present study showed the first evidence that $\beta$-CD treatment may provide an accelerated ripening effect on Cheddar cheese; therefore, further study which will focus on how $\beta-C D$ affects the ripening process will be needed.

\section{ACKNOWLEDGMENTS}

This study was supported by the Brain Korea 21 Project in Seoul, Republic of Korea.

\section{REFERENCES}

Adams, M. L., D. M. Sullivan, R. L. Smith, and E. F. Richer. 1986. Evaluation of direct saponification method in determination of cholesterol in meats. J. Assoc. Anal. Chem. 69:844-846.

AOAC. 1984. Official Methods of Analysis. 4th ed. Association of Official Analytical Chemists, Arlington, VA.

Aston, J. W., J. E. Giles, H. G. Durward, and J. R. Dully. 1985. Effect of elevated ripening temperature on proteolysis and flavour development in Cheddar cheese. J. Dairy Res. 52:565-572.

Cochran, W. G., and G. M. Cox. 1957. Experimental Designs. John Wiley \& Sons, New York, NY.

Creamer, L. K., and N. F. Olson. 1982. Rheological evaluation of maturing Cheddar cheese. J. Food Sci. 47:631-646.

Fernandez-Espla, M. D., and P. F. Fox. 1998. Effect of adding Propiobacterium shermanii NCDO 853 or Lactobacillus casei ssp. casei IFPL 731 on proteolysis and flavor development of Cheddar cheese. J. Agric. Food Chem. 46:1228-1234.

Fox, P. F. 1989a. Proteolysis during cheese manufacture and ripening. J. Dairy Sci. 72:1379-1385

Fox, P. F. 1989b. Acceleration of cheese ripening. Food Biotechnol. 2:133-185.

Fox, P. F., and P. L. H. McSweeney. 1998. Chemistry and biochemistry of cheese and fermented milks. Pages 379-436 in Dairy Chemistry and Biochemistry. P. F. Fox and P. L. H. McSweeney, ed. Blackie Academic \& Professional, London, UK. 
Guinee, T. P. 2003. Role of protein in cheese and cheese products. Pages 1083-1174 in Advanced Dairy Chemistry. P. F. Fox and P. L. H. McSweeney, ed. Kluwer Academic/Plenum Publishers, New York, NY.

Han, E. M., S. H. Kim, J. Ahn, and H. S. Kwak. 2005. Cholesterol removal from homogenized milk with crosslinked $\beta$-cyclodextrin by adipic acid. Asian-Aust. J. Anim. Sci. 18:1794-1799.

Izco, J. M., A. Irigoyen, P. Torre, and Y. Barcina. 2000. Effect of the activity levels of the added proteolytic enzyme mixture on free amino acids in ripening Ossau-Iraty cheese. J. Chromatogr. A 881:69-79.

Kwak, H. S., I. J. Jeon, and J. Park. 1990. Effects of food grade porcine pancreatic lipase on the production of short-chain fatty acids and its contribution. Korean J. Food Sci. Technol. 22:248-254.

Kwak, H. S., I. J. Jeon, and S. K. Perng. 1989. Statistical patterns of lipase activities on the release of short-chain fatty acids in Cheddar cheese slurries. J. Food Sci. 54:1559-1560.

Kwak, H. S., C. S. Jung, S. Y. Shim, and J. Ahn. 2002. Removal of cholesterol from Cheddar cheese by $\beta$-cyclodextrin. J. Agric. Food Chem. 50:7293-7298

Law, B. A. 1984. The accelerated ripening of cheese. Pages 209-228 in Advances in the Microbiology and Biochemistry of Cheese and Fermented Milk. F. L. Davies and B. A. Law, ed. Elsevier Applied Science, London, UK.

Lucey, J. A., M. E. Johnson, and D. S. Horne. 2003. Perspectives on the basis of the rheology and texture properties of cheese. J. Dairy Sci. 86:2725-2743.

McSweeney, P. L. H. 2004. Biochemistry of cheese ripening. Int. J. Dairy Technol. 57:127-144.

Metzger, L. E., and V. V. Mistry. 1994. A new approach using homogenization of cream in the manufacture of reduced fat Cheddar cheese. 1. Manufacture, composition, and yield. J. Dairy Sci. $77: 3506-3515$.
Morris, H. A. 1978. Cheese ripening research-Trends and perspectives. J. Dairy Sci. 61:1198-1204.

O'Keeffe, A. M., P. F. Fox, and C. Daly. 1978. Proteolysis in Cheddar cheese: Role of coagulant and starter bacteria. J. Dairy Res. 45:465-471.

O'Mahony, J. A., M. J. Sousa, and P. L. H. McSweeney. 2003. Proteolysis in miniature Cheddar-type cheeses made using blends of chymison and Cynara cardunculus proteinase as coagulant. Int. J. Dairy Technol. 56:52-58.

O'Mahony, J. A. L., and P. L. H. McSweeney. 2005. Chymison-mediated proteolysis, calcium solubilization, amd texture development during the ripening of Cheddar cheese. J. Dairy Sci. 88:3101-3114.

O'Reilly, C. E., A. L. Kelly, J. C. Oliveira, P. M. Murphy, M. A. E. Auty, and T. P. Beresford. 2003. Effect of varying high-pressure treatment conditions on accerelation of ripening of cheddar cheese. Innov. Food Sci. Emerging Technol. 4:277-284.

SAS Institute. 1985. SAS Users Guide: Statistics. Version 5 ed. SAS Inst. Inc., Cary, NC.

Shakeel-Ur-Rehman, D. Waldron, and P. F. Fox. 2004. Effect of modifying lactose concentration in cheese curd on proteolysis and in quality of Cheddar cheese . Int. Dairy J. 14:591-597.

Smit, G., A. Verheul, R. van Kranenburgm, E. Ayad, R. Siesen, and W. Engels. 2000. Cheese flavor development by enzymatic conversions of peptides and amino acids. Food Res. Int. 33:153-160.

Walstra, P., T. J. Geurts, A. Noomen, A. Jellema, and M. A. J. S. van Boekel. 1999. Cheese ripening and properties. Pages 630-638 in Principles of Milk Properties and Processes. P. Walstra, T. J. Geurts, A. Noomen, A. Jellema, and M. A. J. S. van Boekel, ed. Marcel Dekker Inc., New York, NY.

Yokoyama, H., N. Sawamura, and N. Motobatashi, inventors. 1992. Method for accelerating cheese ripening. Eur. patent 0469857.

Yvon, M. 2006. Key enzymes for flavour formation by lactic acid bacteria. Aust. J. Dairy Technol. 61:88-96. 